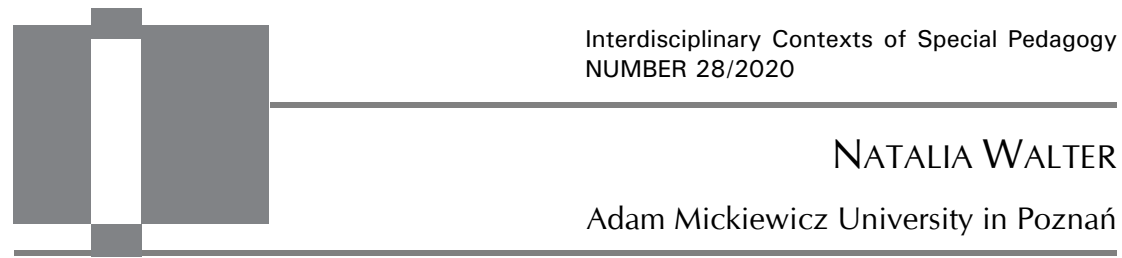

\title{
Online social functioning of students of Polish higher education institutions
}

\begin{abstract}
Natalia Walter, Online social functioning of students of Polish higher education institutions. Interdisciplinary Contexts of Special Pedagogy, no. 28, Poznań 2020. Pp. 77-92. Adam Mickiewicz University Press. ISSN 2300-391X. e-ISSN 2658-283X. DOI: https://doi.org/10.14746/ikps.2020.28.05
\end{abstract}

The paper was devoted to the issue of social functioning of Polish higher education institution students online. The internet is a social space, which offers opportunities for civic engagement, and online political activism; it can also be a place of interactions, such as social support, which lead to the improvement of individual mental well-being. The paper outlines some of the results of a study carried out as part of a State Agency for the Prevention of Alcohol-Related Problems project (40/3.4.3/ 19/DEA) in 2019 on a group of 4503 women and men, studying at Polish higher education institutions. The tool used to study the support was the Multidimensional Perceived Social Support Scale, complemented by statements concerning online support. In order to investigate the phenomenon of social and civic engagement, the study used a scale of 14 statements, developed by Mateusz Marciniak. The results showed that the majority of the respondents (ca. 70\%) never engaged in online fundraising campaigns, did not engage in political disputes online (more than $75 \%$ ) and did not seek social support on the internet.

KEY WORDS: online social support, online social and civic engagement, university students 


\section{Introduction}

The term 'social space' usually concerns a specific and limited area where interactions and communication processes both take place. In the case of the internet, this is connected with the complete disappearance of traditional space-time boundaries. What is more, in this case we are dealing with virtual reality, which - according to some authors - is immaterial and imaginary. Despite that, the internet is considered a social space and its users become part of a larger community. ${ }^{1}$ "The internet is a technology that not only serves the public sphere but also becomes socialised, mirrors this sphere and can be populated or even inhabited", 2 The social space of the internet is referred to as the cyberworld, cyberspace, which is inhabited by virtual society, communities and groups. ${ }^{3}$ The contemporary concepts concerning the internet mostly adopt the approach that both online and offline communities interpenetrate, which makes it difficult to speak of dualism in this regard.

The internet is a tool, which may foster the development of social interaction, despite the lack of physical presence and closeness. ${ }^{4}$ Referring to Bohdan Jałowiecki's urban space theory, Magdalena Szpunar defined the dimensions of the social space of the internet the space of production (creative online activities, business activi-

1 Cf. S. Jones, CyberSociety 2.0: Revisiting Computer-mediated Communication and Community, SAGE Publications, Thousand Oaks, 1998; D. McQuail, Teoria komunikowania masowego, PWN, Warsaw, 2007; M. Castells, Galaktyka Internetu, Dom Wydawniczy REBIS, Poznań, 2003, N. Walter, Internetowe wsparcie społeczne. Studium socjopedagogiczne, Wydawnictwo Naukowe Uniwersytetu im. Adama Mickiewicza w Poznaniu, Poznań, 2016 and more.

2 A. Tarkowski, "Internet jako technologia i wyobrażenie. Co robimy z technologią, co technologia robi z nami?", [in:] Społeczna przestrzeń Internetu, D. Batorski., M. Marody, A. Nowak (eds.), Academica, Warsaw, 2006, p. 30.

${ }^{3}$ N. Walter, Internetowe wsparcie społeczne. Studium socjopedagogiczne, Wydawnictwo Naukowe Uniwersytetu im. Adama Mickiewicza w Poznaniu, Poznań, 2016.

${ }^{4}$ M. Szpunar, "Przestrzeń Internetu - nowy wymiar przestrzeni społecznej", [in:] Media-Komunikacja-Zdrowie: Wyzwania-Szanse-Zagrożenia, B. Aouil, W. Maliszewski (eds.), Wydawnictwo Adam Marszałek, Toruń, 2008, pp. 31-51. 
ties), the space of power (governments, politics), the symbolic (spiritual) space, the space of consumption (leisure activities) and the space of exchange. The space of exchange, which is the most common online space, is conflated by the author with the exchange of information, which encompasses advice, sharing experiences, as well as libels and offensive messages. The space of the internet is technological, informational and social at the same time. The last type of spaces are communities that use and develop the internet. One may analyse them in terms of objective variables (such as living conditions, income, the manner of using the internet), behavioural variables (online behaviour) and subjective variables (concerning awareness - beliefs, opinions, evaluation of social relations). ${ }^{5}$

The development, implementation and dissemination of the Ajax technology ca. 2001 turned out to be a true breakthrough in the process of socialisation of the internet, leading to the emergence of Web 2.0 applications. Existing services, such as e-mail, WWW, discussion lists and groups, as well as online forums, chats and blogs were enhanced with new features. Additionally, a number of solutions have emerged at that time, believed by many internet users to be indispensable. ${ }^{6}$ The development of the internet has led to the emergence of so-called new media (sometimes called the achievement of the Web 3.0 generation) of a more social nature. "Their primary purpose is to connect people and build relationships. Facebook, MySpace and Twitter are the best examples of such services, where the ability to post short, single-line posts encourages users to share their stories, thoughts and emotions with friends". ${ }^{7}$

During the study design phase, the authors decided to take a closer look at the following areas of online social activity of the respondents: 1) political and social activism, 2) engagement in online helping and 3) online social support.

${ }^{5}$ M. Szpunar, "Przestrzeń Internetu - nowy wymiar przestrzeni społecznej", [in:] Media-Komunikacja-Zdrowie: Wyzwania-Szanse-Zagrożenia, B. Aouil, W. Maliszewski (eds.), Wydawnictwo Adam Marszałek, Torun, 2008, pp. 31-51.

${ }^{6}$ N. Walter, Internetowe wsparcie społeczne. Studium socjopedagogiczne, Wydawnictwo Naukowe Uniwersytetu im. Adama Mickiewicza w Poznaniu, Poznań, 2016.

7 P. Levinson, Nowe nowe media, Wydawnictwo WAM, Kraków, 2010. 
Here, it is worth pointing out that ICT are increasingly becoming more and more crucial for political and social activism. In particular, the tools ushered in by the advent of Web 2.0 and social media applications have played a significant role in influencing government decision-making and shaping relationships between governments, citizens, politicians and other social actors. Initially, activists used information technology to promote and disseminate the key ideas and concepts of social movements and to gain global following. Currently, we can see an apparent trend towards integrated use of social media tools and applications, which give rise to a phenomenon, which can be referred to as cyberactivism 2.0.8

Online social support, on the other hand, is closely linked to the concept of human mental well-being, which in turn depends on many factors, one of which includes social support, aimed at helping people in a critical situation. Such an event may be of a normative nature and be an integral part of human development (birth of the first child, starting the first job, death of a spouse), as well as traumatic (unexpected illness in family, a cataclysm, an accident). Support may serve the role of a protective buffer, helping the person experiencing a difficult situation to return to better mental state in shorter time. It is worth noting that the received support does not have to be the same as the support perceived by the supported person. Studies show that the internet may become a space of social support, in particular in situations, which require contact with other people, who share similar experiences. ${ }^{9}$ The manifestations of online social support can be seen in various online services. In difficult situations, internet users usually turn towards thematic websites

${ }^{8}$ R. Sandoval-Almazan, J.R. Gil-Garcia, “Towards cyberactivism 2.0? Understanding the use of social media and other information technologies for political activism and social movements", Government Information Quarterly, Volume 31, Issue 3, 2014, pp. 365-378, https:/ / doi.org/10.1016/j.giq.2013.10.016.

${ }^{9}$ Cf. A. Bambina, Online social support. The Interplay of Social Networks and Computer-Mediated Communication, Cambria Press, New York 2007; N. Walter, Internetowe wsparcie społeczne. Studium socjopedagogiczne, Wydawnictwo Naukowe Uniwersytetu im. Adama Mickiewicza w Poznaniu, Poznań, 2016. 
and online forums, they also read blogs, social networking websites and discussion groups, but less often than the former. Usually they look for information, followed by instrumental support. They rarely seek emotional, spiritual and material support. ${ }^{10}$

\section{Literature review}

The studies encompassing young internet users (Nastolatki 3.0. Raport z ogólnopolskiego badania uczniów, Bochenek, Lange (eds.), 2019; Polskie badania EU Kids Online 2018. Najważniejsze wyniki i wnioski, Pyżalski et al., 2019) indicate that the number of children and youth who are constantly connected to the internet is on the rise. Just like young people, the adults also never let go of their smartphones, which give them unfettered and unlimited access to the internet, and they use them no matter what kind of activity they participate in. This "background" use blurs the boundaries between "online" and "offline" life. It is therefore necessary to examine how and how often students of higher education institutions use the internet, and whether there are any correlations between their online activities and risky or pro-social behaviours.

The contemporary students are considered to be a generation that has internalised media convergence and that knows how to use various digital devices and media, as well as one that is endowed with social awareness that the previous generations did not have. According to a Havas Media study on young prosumers ${ }^{11}$ among this generation, in $201147 \%$ of the population aged 18-25 considered themselves prosumers. They explained the fact that that the majority of them solely consumed content, rather than actually produced it by claiming that sharing content created by others is a form

10 N. Walter, Internetowe wsparcie społeczne. Studium socjopedagogiczne, Wydawnictwo Naukowe Uniwersytetu im. Adama Mickiewicza w Poznaniu, Poznań, 2016.

${ }^{11}$ Euro RSCG Worldwide, "Millenials: The Challenger Generation", Prosumer Report, vol. 11, p. 4, 2001 http://www.prosumer-report.com/blog/wpcontent/ uploads/2011/04/MGv16no\%20crops.pdf, retrieved on: 29.11.2019. 
of creating new content. For these people, sharing the information they read is part of their social engagement. ${ }^{12}$ Studies carried out by EU Kids and NASK ${ }^{13}$ have highlighted even lower creative involvement of younger internet users.

It is difficult to unequivocally claim whether online social support is widespread among studying women and men, who are predominantly young adults. According to Natalia Walter's study, less than half of pedagogy students surveyed declared that they would take advantage of online support in a critical situation, or a situation they personally would perceive as exceeding their ability to cope with it on their own. ${ }^{14}$

\section{Methodology}

The study was carried out in 2019 on a group of 4503 students of Polish higher education institutions, which was representative in terms of gender, place of residence and institution type.

Table 1. Study group - course type $(\mathrm{N}=4503)$

\begin{tabular}{|l|c|c|c|c|}
\hline & Frequency & Percentage & $\begin{array}{c}\text { Valid } \\
\text { percentage }\end{array}$ & $\begin{array}{c}\text { Cumulative } \\
\text { percentage }\end{array}$ \\
\hline Part-time courses & 1588 & 35.3 & 35.3 & 35.3 \\
\hline Full-time courses & 2915 & 64.7 & 64.7 & 100.0 \\
\hline Total & 4503 & 100.0 & 100.0 & \\
\hline
\end{tabular}

12 M. Sánchez Martínez, R. I. Alonso,"Convergence and interaction in the new media: typologies of prosumers among university students", Communication $\mathcal{E}$ Society, 2015, pp. 87-99. https://doi.org/10.15581/003.28.2.87-99.

13 J. Pyżalski, A. Zdrodowska, Ł. Tomczyk, K. Abramczuk, Polskie badania EU KIDS ONLINE. Najważniejsze wyniki i wnioski, Wydawnictwo Naukowe Uniwersytetu im. Adama Mickiewicza w Poznaniu, Poznań, 2019; M. Bochenek, R. Lange, NASTOLATKI 3.0. Raport z ogólnopolskiego badania uczniów, NASK Państwowy Instytut Badawczy, Warsaw, 2019.

${ }^{14} \mathrm{~N}$. Walter, Internetowe wsparcie społeczne. Studium socjopedagogiczne, Wydawnictwo Naukowe Uniwersytetu im. Adama Mickiewicza w Poznaniu, Poznań, 2016. 
The survey was attended by 1588 (35.3\%) persons attending part-time courses, as well as 2915 (64.7\%) persons attending fulltime courses and study programmes.

The group of respondents included 3052 women $(67.8 \%)$ and 1322 men (29.4\%). According to data provided by Statistics Poland, in the academic year 2018/19 women constituted $58.0 \%$ of all students. Approximately 809,300 people signed up for full-time study programmes, making up $65.8 \%$ of all students, while approximately 421,000 signed up for part-time courses. ${ }^{15}$ Therefore, it can be assumed that the distribution of the respondents is consistent with the nationwide distribution observed at higher education institutions.

Table 2. Study group - gender $(\mathrm{N}=4503)$

\begin{tabular}{|l|l|r|r|c|c|}
\hline \multicolumn{2}{|c|}{} & Frequency & Percentage & $\begin{array}{c}\text { Valid } \\
\text { percentage }\end{array}$ & $\begin{array}{c}\text { Cumulative } \\
\text { percentage }\end{array}$ \\
\hline \multirow{3}{*}{ Note } & woman & 3052 & 67.8 & 69.8 & 69.8 \\
\cline { 2 - 6 } & man & 1322 & 29.4 & 30.2 & 100.0 \\
\cline { 2 - 6 } & Total & 4374 & 97.1 & 100.0 & \\
\hline No data & Systemic data gaps & 129 & 2.9 & & \\
\hline Total & 4503 & 100.0 & & \\
\hline
\end{tabular}

The majority $(85.9 \%)$ of the surveyed group were people born after 1992, who are members of the group of the so-called young adults.

The fragment of the study presented in this paper concerned the use of the internet by students. $95 \%$ of the respondents declared that they connect to the Internet using at least one of the following devices - a smartphone/mobile phone, desktop computer/laptop placed in a specific place at home, laptop they carry with them, a tablet, a sports wristband/smart watch, a console, a TV set. The respondents indicated that they most commonly used their smartphones

15 Statistics Poland (GUS), Szkolnictwo wyższe w roku akademickim 2018/2019 (wyniki wstepne), 2019. 
and mobile phones to connect to the internet $(82.1 \%$ of all respondents).

In order to examine the perceived social support among students, the authors used the Multidimensional Perceived Social Support Scale. ${ }^{16}$ Additionally, the respondents were asked questions concerning online social support. The Likert scale employed in the study included values from: 1 - I strongly disagree to 7 - I strongly agree.

To investigate the phenomenon of social and civic engagement, the authors used a scale designed and developed by Mateusz Marciniak, comprising 14 questions; however, this paper focuses only on selected items concerning online functioning. The responses were provided in the form of a cafeteria, and the respondents were to indicate whether they had undertaken particular activities during the last year or earlier (described as "various activities undertaken by some people"). Each statement could be answered with "yes" or "no" (multiple choice, with the following available responses: "during the last year", "earlier during my studies" and "before studying").

\section{Results}

By far the largest source of support for female and male students are people from their immediate social circles (indicated by 70 to $80 \%$ of all respondents). Online social support is less appreciated, but remains quite important. The search for online social support takes place independently of the supportive presence of people from the immediate social circles, although a certain correlation cannot be fully excluded. Social support offered by the immediate

${ }^{16}$ G. Zimet, N. Dahlem, S. Zimet, G. Farley, “The Multidimensional Scale of Perceived Social Support", Journal of Personality Assessment, 52(1), 1998, pp. 30-41; Polish version: K. Buszman, H. Przybyła-Basista, "Polska adaptacja wielowymiarowej skali spostrzeganego wsparcia społecznego", Polskie Forum Psychologiczne, vol. 22, no. 4, 2017, pp. 581-599. 
Table 3. Offline and online social support $(\mathrm{N}=4511)$

\begin{tabular}{|c|c|c|c|c|c|c|c|}
\hline & 1 & 2 & 3 & 4 & 5 & 6 & 7 \\
\hline & $\%$ & $\%$ & $\%$ & $\%$ & $\%$ & $\%$ & $\%$ \\
\hline $\begin{array}{l}\text { 1) There is a special person who is always } \\
\text { nearby when I am in need }\end{array}$ & 2.4 & 3.3 & 5.2 & 8 & 13.5 & 19.9 & 47 \\
\hline $\begin{array}{l}\text { 2) There is a special person with whom I } \\
\text { can share my joys and sorrows }\end{array}$ & 2 & 2.8 & 5.3 & 7 & 11 & 20.1 & 50.8 \\
\hline 3) My family is really trying to help me & 1.5 & 2.8 & 7.3 & 8.9 & 14.1 & 20.7 & 43.8 \\
\hline $\begin{array}{l}\text { 4) I receive the emotional help and sup- } \\
\text { port I need from my family }\end{array}$ & 2.2 & 3.7 & 6.7 & 10.5 & 15.3 & 21.5 & 39.2 \\
\hline $\begin{array}{l}\text { 5) I have a special person who is a real } \\
\text { source of comfort / support for me }\end{array}$ & 2.4 & 2.8 & 4.8 & 8.5 & 10.5 & 19.4 & 50.6 \\
\hline 6) My friends are really trying to help me & 1.7 & 2.9 & 6.6 & 11.8 & 18.4 & 25.2 & 32.5 \\
\hline $\begin{array}{l}\text { 7) I can count on my friends when some- } \\
\text { thing goes wrong }\end{array}$ & 2 & 3.2 & 6.3 & 11.5 & 17.7 & 25.7 & 32.9 \\
\hline $\begin{array}{l}\text { 8) I can talk to my family about my prob- } \\
\text { lems }\end{array}$ & 3.4 & 5.2 & 9 & 11 & 16.5 & 21.4 & 32.5 \\
\hline $\begin{array}{l}\text { 9) I have friends with whom I can share } \\
\text { my joys and sorrows }\end{array}$ & 1.8 & 3.1 & 6.5 & 10.1 & 15.3 & 25.6 & 36.6 \\
\hline $\begin{array}{l}\text { 10) There is a special person in my life } \\
\text { who cares about my feelings }\end{array}$ & 3.3 & 3.5 & 5.7 & 9.1 & 11.6 & 17.5 & 48.5 \\
\hline $\begin{array}{l}\text { 11) My family is happy to help me make } \\
\text { decisions }\end{array}$ & 3.1 & 4.5 & 7.9 & 12.8 & 17.9 & 21 & 32 \\
\hline $\begin{array}{l}\text { 12) I can talk to my friends about my } \\
\text { problems }\end{array}$ & 2.2 & 4.2 & 6.8 & 11.3 & 16 & 24.7 & 33.9 \\
\hline $\begin{array}{l}\text { 13) In a difficult situation I look for sup- } \\
\text { port on the internet (e.g. online sup- } \\
\text { port groups) }\end{array}$ & 41.4 & 16.9 & 11.4 & 11 & 7.9 & 6.2 & 4 \\
\hline $\begin{array}{l}\text { 14) I look up information about the issues I } \\
\text { have online }\end{array}$ & 21.3 & 16.2 & 14.8 & 14.2 & 15.4 & 9.8 & 7.2 \\
\hline $\begin{array}{l}\text { 15) I talk online to experts about my issues } \\
\text { and problems, for example concerning } \\
\text { my health }\end{array}$ & 55.5 & 13.6 & 7.7 & 8.2 & 5.4 & 4.8 & 3.7 \\
\hline $\begin{array}{l}\text { 16) I can count on a virtual support group } \\
\text { (online) when I go through hard times }\end{array}$ & 62.4 & 11.7 & 6.4 & 7.6 & 4.1 & 3.5 & 3 \\
\hline
\end{tabular}


social circles is noticed more often by women compared to men ( $x 2=195.778$, with $\mathrm{p}<0.0001)$, whereas such a difference cannot be indicated for online support. Childfree and childless people are more likely to take advantage of online support compared to parents $(\chi 2=62,921$, at $p<0,0001)$.

For a more complete visualization of the results, the authors have combined positive answers (5, 6, 7 on the Likert scale, from "I rather agree" to "I fully agree"). This summary is shown in Figure 1.

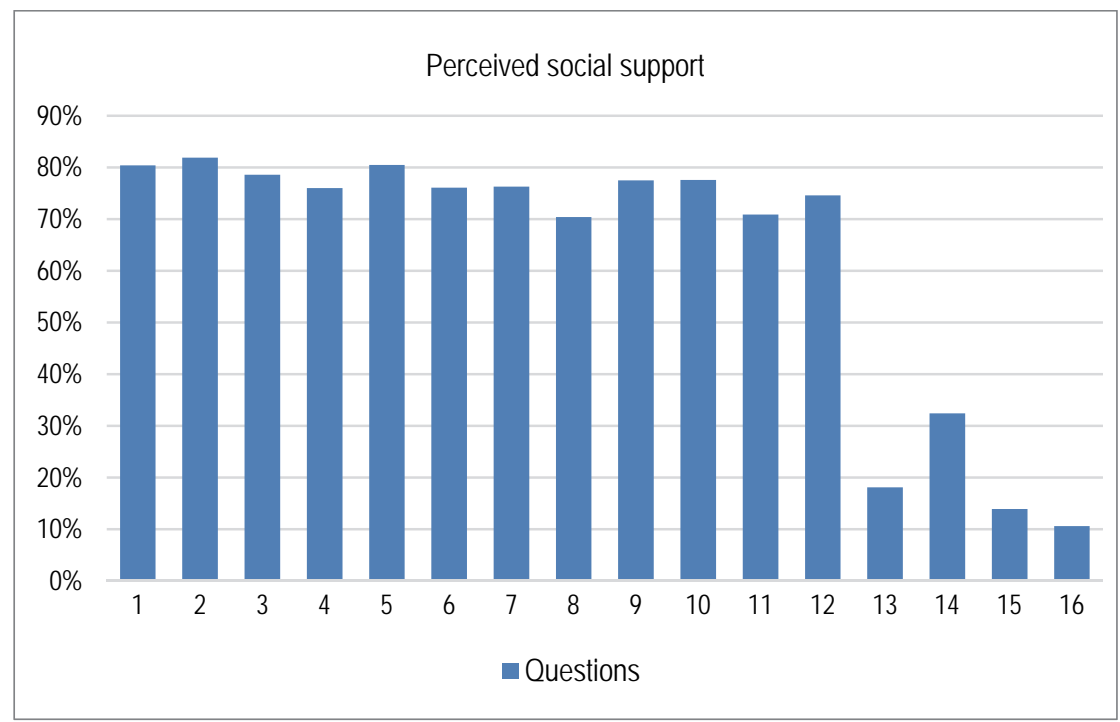

Fig. 1. Perceived social support $(\mathrm{N}=4470)$

It is worth noting that students are rarely eager to take advantage of online social support, when it requires contact with other people who are online (e.g. support groups - $10.6 \%$, as well as specialists $-13.9 \%)$. On the other hand, they more often tend to seek anonymous support $(32.4 \%)$, not linked in any way to a specific person or a group, on their own - by searching for specific information. 
As far as participation in charity fundraising campaigns or social activities using online crowdfunding websites such as Siepomaga is concerned, more than $70 \%$ of the respondents have never been involved in such activities. The responses to the question concerning participation in offline fundraising campaigns (for example participating in organisation of a charity event, charity race etc.) were similar. $39.3 \%$ of all respondents declared that they signed petitions concerning social or political issues, including on the internet. $22.7 \%$ of respondents have ever discussed political issues online, while $46.8 \%$ of students engaged in such disputes face to face, although it needs to be noted that the authors do not know who initiated these debates - students themselves or, for example, family members or friends.

Table 4. Diversification of the respondents in terms of social and civic engagement $(\mathrm{N}=4503)$

\begin{tabular}{|l|c|c|c|c|}
\hline $\begin{array}{c}\text { Forms of social and civic } \\
\text { engagement (statements from } \\
\text { the social and civic engage- } \\
\text { ment scale) }\end{array}$ & NO & $\begin{array}{c}\text { YES, } \\
\text { during the } \\
\text { last year }\end{array}$ & $\begin{array}{c}\text { YES } \\
\text { (earlier) }\end{array}$ & No data \\
\cline { 2 - 5 } & $\%$ & $\%$ & $\%$ & $\%$ \\
\hline $\begin{array}{l}\text { I actively participated in raising } \\
\text { funds for social/charitable activ- } \\
\text { ities through a crowdfunding } \\
\text { website or another online outlet } \\
\text { (such as siepomaga.pl) }\end{array}$ & 70.9 & $\mathbf{1 8 . 3}$ & 8.7 & 2.1 \\
\hline $\begin{array}{l}\text { I have signed letters/petitions } \\
\text { (including online ones) concern- } \\
\text { ing social or political issues }\end{array}$ & 58.7 & $\mathbf{2 9 . 7}$ & 9.5 & 2.1 \\
\hline $\begin{array}{l}\text { I have discussed social or politi- } \\
\text { cal issues during meetings with } \\
\text { other people (for example friends } \\
\text { and family) }\end{array}$ & 51.3 & $\mathbf{4 1 . 4}$ & 5.4 & 1.9 \\
\hline $\begin{array}{l}\text { I have discussed social or politi- } \\
\text { cal issues online with other } \\
\text { people }\end{array}$ & 75.5 & $\mathbf{1 6 . 3}$ & 6.4 & 1.8 \\
\hline
\end{tabular}


During the analysis of the social engagement of students on the internet, the authors referred to their participation in the daily help activities. It turns out that more often people who participate in offline help activities get involved in online help activities as well $\left(\chi^{2}=866.929\right.$; at $\left.\mathrm{p}<0.0001\right)$.

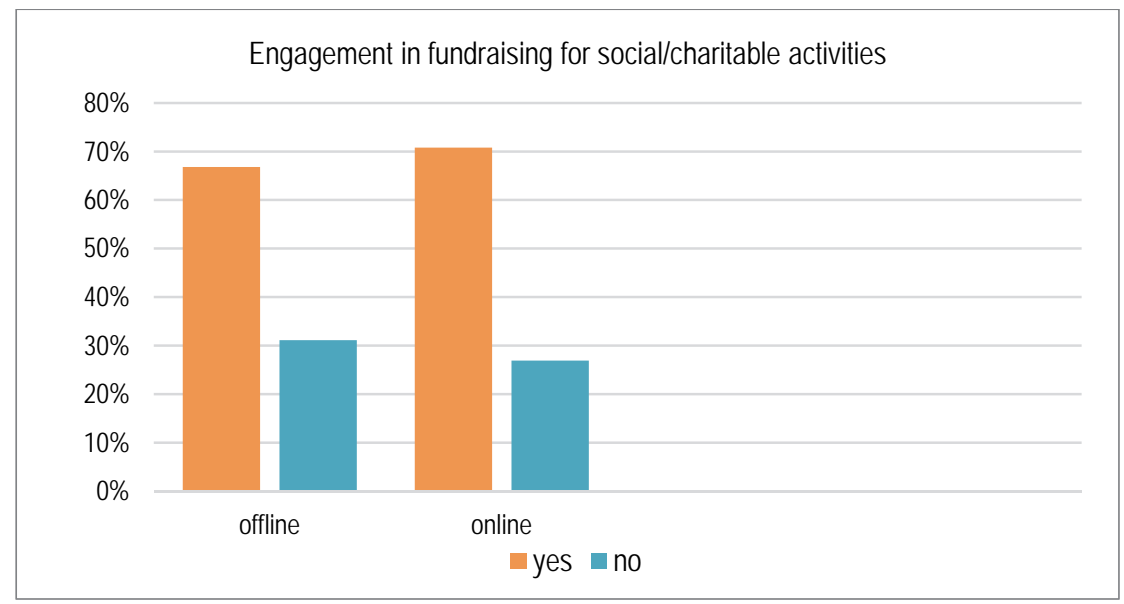

Fig. 2. Students' engagement in fundraising for social/charitable activities $(\mathrm{N}=4503)$

As it was the case with offline engagement, women are slightly more eager to help online (28.8\%) compared to men $(23.6 \%)$ $\left(\chi^{2}=12.991\right.$, at $\left.p=0.002\right)$. Interestingly, online support is more often taken advantage of by people who have never been involved in online charities (fundraising via crowdfunding websites) than those who have done so $\left(x^{2}=105,233\right.$, at $\left.\mathrm{p}<0,0001\right)$.

\section{Discussion and conclusion}

Young adulthood, which is the period of development characteristic of the majority of the respondents is one of the first periods of development in which a person encounters critical events that 
result in the state of mental imbalance. Such critical events result in different emotional outcomes. Some of them are two-valued in their emotional nature, for example giving birth to a child (ranging from fear during childbirth to great joy) or graduating from school (the difficulties of exams vs. satisfaction with the result), others are associated with positive emotions (for example meeting a partner, success at work, at the university, finding a new apartment), and others are associated with negative emotions (for example failure at the university, at work, loss of a loved one). ${ }^{17}$ Thus, the development tasks in young adulthood require, on the one hand, intellectual maturity, together with the ability to cope with problems and solve them, and on the other hand, emotional and social maturity, connected with taking responsibility for oneself and others. ${ }^{18}$ The young adulthood age is characterised by optimistic dreams about the future; however, people at that age rarely think about possible difficulties. Parenthood, which is usually the closest normative critical event in the lives of young adults, also appears to be wonderful and full of happiness. It is therefore probably impossible for students to predict whether they would take advantage of online support in a situation of parental stress and whether they would be ready to participate in virtual support groups. The lack of interest in online support may also result from other issues that are described in the subject literature, such as individual ways of coping with stress, personality traits that exclude taking advantage of external resources, as well as supportive immediate circles acting as a kind of cocoon that guarantees safety. ${ }^{19}$ In the case of young adults, who

${ }^{17}$ H. Sęk, A. Sommerfeld, Być dorostym?! Centrum Doskonalenia Nauczycieli im. W. Spasowskiego, Legnica, 1990.

${ }_{18}$ M. Kielar-Turska, "Rozwój człowieka w pełnym cyklu życia", [in:] Psychologia. Podręcznik akademicki. Podstawy psychologii, ed. J. Strelau, vol. 1, Gdańskie Wydawnictwo Psychologiczne, GWP, 2006, pp. 281-387.

${ }^{19}$ H. Sęk., R. Cieślak, "Wsparcie społeczne - sposoby definiowania, rodzaje i źródła wsparcia, wybrane koncepcje teoretyczne", [in:] Wsparcie społeczne, stres i zdrowie, H. Sęk, R. Cieślak (eds.), Wydawnictwo Naukowe PWN, Warsaw, 2004, pp. 11-28. 
usually do not yet have strong support from their spouse and other people, the need of external help, including help sought online, arises somewhat more often. However, due to their age and the fact that they rarely ever experienced a critical event, they are rarely the main recipients of social support and they rarely offer it. As shown in studies carried out by other authors, people who are pro-social, open, active, who exhibit critical thinking are usually involved in providing online social support. ${ }^{20}$ The paper shows that students are rarely eager to take advantage of online social support when it requires getting in touch in other people who are online, as they usually look for anonymous support, not linked to a specific person or group of people. Such a distribution shows that in the case of a critical event, the most important things include professional information, only followed by the possibility of talking to other people facing similar difficulties.

According to the concept coined by Havighurst, 21 in young adulthood (23-34 years old) a person should choose a life partner; learn to live with a partner; take on family roles; look after children; run the home; start a career; take on civic responsibility and choose the right social group. Young adulthood is the period when people make the most important decisions in life, "which require making a conscious choice and at the same time great ability to adapt creatively to the new tasks required in the professional and family setting." 22 According to many authors, responsibility - which takes the form of consciously making decisions about one's own life and accepting responsibility for the other, as well as autonomy, which corresponds to territorial and material independence - is the essence of adulthood. The presented study shows that social engagement in online activities, both in terms of political cyberactivism

${ }^{20}$ N. Walter, Internetowe wsparcie społeczne. Studium socjopedagogiczne, Wydawnictwo Naukowe Uniwersytetu im. Adama Mickiewicza w Poznaniu, Poznań, 2016.

${ }^{21}$ R.J. Havighurst, Human Development and Education, Longman, New York, 1981.

${ }^{22}$ H. Sęk, A. Sommerfeld, Być dorostym?! Centrum Doskonalenia Nauczycieli im. W. Spasowskiego, Legnica, 1990, p. 10. 
and participation in support campaigns is rather seldom. The willingness of students to use the internet does not translate into empathic or altruistic online and offline activities. This is most likely due to a certain prevailing attitude concerning making conscious decisions about their own life and autonomy, which - with age may be gradually directed towards accepting full responsibility for the other and for society. The development of digital skills during school education, which so far has rather focused purely on instrumental aspects, as well as the negative image of the internet, also seems to be not without significance.

\section{References}

Bambina A., Online social support. The Interplay of Social Networks and ComputerMediated Communication, Cambria Press, New York, 2007.

Bochenek M., Lange R., NASTOLATKI 3.0. Raport z ogólnopolskiego badania uczniów, NASK Państwowy Instytut Badawczy, Warsaw, 2019.

Buszman K., Przybyła-Basista H., “Polska adaptacja wielowymiarowej skali spostrzeganego wsparcia społecznego", Polskie Forum Psychologiczne, vol 22, no. 4, 2017, pp. 581-599.

Castells M., Galaktyka Internetu, Dom Wydawniczy REBIS, Poznań, 2003.

Euro RSCG Worldwide, "Millenials: The Challenger Generation", Prosumer Report, vol. 11, p. 4, 2001 http://www.prosumer-report.com/blog/wpcontent/uploads/ 2011/04/MGv16no\%20crops.pdf, retrieved on: 29.11.2019.

Statistics Poland (GUS), Szkolnictwo wyższe w roku akademickim 2018/2019 (wyniki wstepne), 2019.

Jones S., CyberSociety 2.0: Revisiting Computer-mediated Communication and Community, SAGE Publications, Thousand Oaks, 1998.

Levinson P., Nowe nowe media, Wydawnictwo WAM, Krakow, 2010.

McQuail D., Teoria komunikowania masowego, PWN, Warsaw, 2007.

Pyżalski J., Zdrodowska A., Tomczyk Ł., Abramczuk K., Polskie badania EU KIDS ONLINE. Najważniejsze wyniki i wnioski, Wydawnictwo Naukowe Uniwersytetu im. Adama Mickiewicza w Poznaniu, Poznań, 2019.

Szpunar, M. "Przestrzeń Internetu - nowy wymiar przestrzeni społecznej”, [in:] Media-Komunikacja-Zdrowie: Wyzwania-Szanse-Zagrożenia, B. Aouil, W. Maliszewski (eds.), Wydawnictwo Adam Marszałek, Torun, 2008, pp. 31-51.

Sánchez Martínez M., Alonso R.I., "Convergence and interaction in the new media: typologies of prosumers among university students", Communication \& Society, 2015, pp. 87-99. https://doi.org/10.15581/003.28.2.87-99. 
Sandoval-Almazan R., Gil-Garcia J.R., Towards cyberactivism 2.0? Understanding the use of social media and other information technologies for political activism and social movements", Government Information Quarterly, Volume 31, Issue 3, 2014, pp. 365-378, https:/ / doi.org/10.1016/j.giq.2013.10.016.

Tarkowski A., “Internet jako technologia i wyobrażenie. Co robimy z technologią, co technologia robi z nami?", [in:] Społeczna przestrzeń Internetu, D. Batorski., M. Marody, A. Nowak, Academica, Warsaw, 2006, pp. 23-38.

Walter N., Internetowe wsparcie społeczne. Studium socjopedagogiczne, Wydawnictwo Naukowe Uniwersytetu im. Adama Mickiewicza w Poznaniu, Poznań, 2016.

Zimet G., Dahlem N., Zimet S., Farley G., “The Multidimensional Scale of Perceived Social Support", Journal of Personality Assessment, 52 (1), 1998, pp. 30-41.

Havighurst R.J., Human Development and Education, Longman, New York, 1981.

Sęk H., Sommerfeld A., Być dorostym?! Centrum Doskonalenia Nauczycieli im. W. Spasowskiego, Legnica, 1990.

Sęk H., Cieślak R., “Wsparcie społeczne - sposoby definiowania, rodzaje i źródła wsparcia, wybrane koncepcje teoretyczne", [in:] Wsparcie społeczne, stres i zdrowie, H. Sęk, R. Cieślak (eds.), Wydawnictwo Naukowe PWN, Warsaw, 2004, pp. 11-28.

Kielar-Turska M., "Rozwój człowieka w pełnym cyklu życia”, [in:] Psychologia. Podręcznik akademicki. Podstawy psychologii, ed. J. Strelau, vol. 1, Gdańskie Wydawnictwo Psychologiczne, Gdańsk, 2006, pp. 281-387. 